\title{
The Effect of Context on Meaning Representation of Adjectives such as Big and Large in Translation from Different Languages such as Russian, Persian and Azeri to English Language Texts
}

\author{
Malahat Shabani Minaabad \\ Department of English language, University of Mohaghegh Ardabili, Ardabil, Iran \\ Email: Shabaniml85@Yahoo.Com
}

\begin{abstract}
People's understanding of the meaning of sentences is far more reliable than their understanding of the meaning of words. Since what people know when they know the meaning of a word is important, but the skill of incorporating that word appropriately into meaningful linguistic contexts is more important. Our interest here lies in the shift of emphasis from referential or dictionary meaning to contextual meaning of adjectives such as big and large in translation to English language texts or vice versa. Since big and large are synonyms, it is not surprising that they can be used to describe many of the same nouns. However, they are not perfect synonyms, and there are some differences in the distribution of these adjectives which make some problems for translators especially from those languages which these kinds of differences are not so obvious. Therefore, a comparison of the lists of the words which occurred only with big and those which occurred only with large in English should reveal some differences in translations.
\end{abstract}

Index Terms - large, big, English, referential and contextual meaning

\section{INTRODUCTION}

Translation, as an activity, has been a task which has been performed for centuries. This is an activity whose main concern is to facilitate the communication process. The professional of translation reaches this goal by translating the information received in a foreign language into the language of the person who required his services, and vice versa. When this complex process is carried out in a factual communicative situation, then, it is possible to say that translation has reached its ultimate goal. Translation studies (TS) relies so heavily on a concept of meaning, that one may claim that there is no TS without any reference to meanings. However, different approaches in TS refer to different types of meaning: some researchers are looking for lexical patterns in source texts and their translations (Nilsson, 2002), while other scholars concentrate on how the text utterances function within their immediate contexts (Nord, 1997). Or while some studies are investigations of the impact of the text as a whole on its audience or even society (Venuti, 1998), others refer to philosophy of language as a means to look at meaning in translation (Malmkjær, 1993). If we assume that the goal of both learning a L2 and translating into another language is to transmit appropriate meaning linguistically, semantically, and pragmatically, then learning a L2 should be linked to translation exercises.

Some researchers explicitly talk about meaning as a cognitive concept and say, for instance, that translators and interpreters construct or assemble meaning (Dancette, 1997; Setton, 1999). Others regard it as a textual characteristic. In the latter view, texts themselves hold meanings, so translations can be compared in terms of meanings with each other, with source texts or with a comparable corpus. Taking into account the lexicological aspect, a translator should be knowledgeable of the formation of words in the languages he works from and into, and the semantic relations held among these words, above all in specialized contexts. Sometimes, translators, as linguistic mediators, may face the situation of solving lexical problems, that is, translators are not able to find an appropriate linguistic resource in the target language which properly transmits the message. As Zohrevandi (1992) points out "translation now deals with communicative needs and purposes for stretches of written or oral discourse [...] what Dell Hymes calls communicative competence" (p. 182).

On the other hand, another term for clarifying the meaning in translation is contextualization. Contextualization is not exclusively linguistic, of course; using context to determine linguistic meaning is simply a special case of a general cognitive ability. Contextualization has been defined as the use of context to determine meaning and to resolve potential ambiguities. When contextualization is linked so closely to meaning, of course, it inherits all the uncertainties associated with the concept of meaning. But it also inherits the broad scope of meaningfulness. Wherever experience is meaningful, context must be considered and language provides one of the best avenues to approach a study of the 
remarkable human capacity to use context. A contextual approach to lexical semantics might assume that the meanings of a word form are fully reflected in appropriate aspects of the relations it contracts with actual and potential contexts (Cruse, 1986, p.1).

The easiest place to study contextualization is surely in the relation between words and their contexts of use. Knowing a word involves knowing its meaning and therefore, in my view, knowing a word involves knowing its contexts of use. Consequently, people communicate via sentences, seldom via isolated words. Their intuitions about the definitions of the words they utter and understand are fragmentary at best.

\section{DISCUSSION}

Our interest here lies in the shift of emphasis from referential or dictionary meaning to contextual meaning. The meaning of a given word or set of words is best understood as the contribution that word or phrase can make to the meaning or function of the whole sentence or linguistic utterance where that word or phrase occurs. The meaning of a given word is governed not only by the external object or idea that particular word is supposed to refer to, but also by the use of that particular word or phrase in a particular way, in a particular context, and to a particular effect. Thus, there is a difference between the referential meaning of a word and the contextual meaning of the same word. Let us consider, for example, a couple of lexical items, big and large which are considered synonymous in the world of nonlinguistic reality, but are not simply used alternatively in free variation on each other.

Thus in most cases if the translation or the interpretation was carried out only on a word level it would either produce utterances that sound very unnatural to the native speaker of the target language or it would distort the meaning. On the other hand, since big and large or are synonyms, it is not surprising that they can be used to describe many of the same nouns. However, they are not perfect synonyms, and there are some differences in the distribution of these four adjectives which make some problems for the translators. On the other hand when the translation is taking place across two different languages that do not have culture in common, it is often difficult to obtain even the lexical equivalent of a given items in translation. In order to elaborate these differences in detail, we will try to give the translation of given examples in different languages namely Russian, Persian and Azeri. As mentioned above, the main question here is that since there are not any differences between the mentioned adjectives in some other languages, how translators can make a distinction between them in English or vice versa. For answering these kinds of questions, comparing the list of the words which occurred only with big and those which occurred only with large in English should reveal some differences and may put an end to some confusing.

Large but not big is used with the nouns amount, number, and quantity, so it would be surprising to find these nouns on the list of nouns which occur significantly often with big, and the words that occurred significantly often with big but not large, shows that big does not occur significantly often with any Quantity Nouns. Other categories which occur significantly often with big but not with large are Actions words, Popular Things, Important, Serious Things and Head of Idioms. With all of these nouns, big is describing something other than physical size. For example, with the nouns listed under Actions, big describes the intensity of the action, that is, the amount of energy involved and / or the strength of the effect. A big lift is one that lifts something very high and a big push is one that involves a lot of energy and which moves something a long way. The meaning of big with the Action nouns is quite similar to the meaning with some of the Amount nouns, such as change and drop. For example:

You could notice when the little change began so that you would be better prepared for the big change that might be coming.

(in Russian) Bы могли заметить, когда небольшие изменения начались так, чтобы Вам быть лучше подготовленным к большим изменениям, которые могли бы произойти.

(in persian) Agar motevajehe shoroe tagirate kuchek va joz bashid baraye tagire bozorgi ke ehtemalan dar rah ast behtar amade mishavid.

(in Azari) Kiçik dəyişiklik baş verməyə başladı̆̆ı anda siz onu hiss edəcəksiniz, odur ki, siz galacək böyük dəyişikliya daha da yaxşı hazır olmalısınız.

In fact, most of the Amount nouns which occur with big could probably be considered Actions rather than (or in addition to) Amounts. I have distinguished the two types here mainly because the Amounts are somewhat more abstract in meaning than the Actions and because some of the Amounts (e.g. cut, drop, increase) also occur significantly often with large, but large does not occur significantly often in the corpus with any Actions. Although there are some contexts in which large may be able to modify some of the Action nouns (e.g., a large boost in the polls), it sounds quite strange with most of them (e.g. ? a large jump, ? a large splash).

The nouns listed under Important, Serious Things name things which are not necessarily important or serious in themselves, but which are interpreted as such when modified by big; in other words, it is big that contributes the meaning of important or serious to phrases such as big news and big factor. Project, one of the nouns seems to belong to this category--a big project is a project that is important. Project, of course occurred significantly often with large as well as big.

Unlike project, most of the nouns categorized as Important, Serious Things cannot easily be quantified in terms of dollars or other units of measurement, which may explain why phrases such as ?large news and ?large test do not occur. The same kind of explanation can account for the fact that large does not sound especially awkward with a few Action 
nouns such as large boost and large impact; in some contexts, at least, these nouns describe things that can be easily quantified

Another category which occurs with big is Heads of Idioms. While large did not occur significantly often in any idiomatic adjective+noun phrases, big forms idioms with several nouns, for example, big band (a band that plays a particular kind of music, not a band with a lot of members) and the big bang (the explosion that is supposed to have created the universe). Some nouns have both literal interpretations (usually as Physical Objects) and idiomatic interpretations with big. For example, big picture can be used to refer to a drawing, painting or photograph which is large in size, and it also has two idiomatic interpretations; it can mean something like 'an overall view or understanding of a situation', and it can be used to refer to a successful movie. Obviously, large cannot take the place of big in any of the idiomatic phrases. With many of these nouns large sounds extremely awkward, e.g., ??large bucks, ??large name, ??large talk; In the cases where large sounds fine, the noun is always interpreted literally (e.g., large fish, large band, and large business). In some of the idiomatic phrases, the meaning of big is quite similar to its meaning with the Important, Serious Things. For example:

A big head has a big ache.

(in Russian) У большого человека-большие проблемы.

У большого человека и проблемь большие.

(in Persian). Sare bozorg darde ziyadi ham darad. " harke bamash bish barfash bish”

(in Azari). Böyük başın böyük də ağrısı olar.

However, as it mentioned, there are many nouns from these categories which occur only with big or only with large. Perhaps the most striking pattern is that large occurs significantly often with many more Physical Objects than big does. This is somewhat surprising given the dictionary descriptions of big and large; since the basic meaning of both big and large seems to involve physical size, it might be expected that all of the Physical Objects nouns on the large list could also occur with big. Certainly, big does not sound as awkward with these nouns as it does with the Quantity Nouns. That is, although bag, bowl, and buildings do not occur on the big list, the phrases big bag, big bowl, and big building do not sound very strange, and they sound more natural than big quantity or big degree. The question here, then, is why large is preferred with nouns of this type. In many cases, it may be because large is used (along with small and medium) to describe a standard size of food and household items. Many of the nouns which occur with large but not big fall into this category (e.g., bowl, eggs, onions, skillet, and tomatoes), while none of the Physical Objects nouns which occur with big do. However, this does not explain why large is preferred with nouns such as flowers, garden, and rock. Register differences may play a role here; if, as dictionaries suggest, large is more formal than big, then perhaps large is chosen over big because this written corpus is relatively formal.

Another difference between big and large with the Physical Objects nouns is that many of the nouns that occur with big but not large seem to be describing something other than purely physical size. Many of these nouns describe people (boy(s), guard, guy(s), and kid) or parts of people's body (mouth and toe). While big can describe purely physical size with these nouns, all of them except guard also have idiomatic interpretations, e.g., big kid meaning 'older kid', big toe referring to 'a particular toe', and big mouth, in sentences such as He's got a big mouth, used to talk about someone who says something he should not say. With grin and smile, big seems to be describing intensity rather than, or in addition to, physical size, so these two nouns seem similar to the nouns in the Actions category. If all of these nouns are weeded out, there are only a few nouns with which big have a purely physical interpretation, i.e., bar, boats, gap, guard, and tent. For example:

In earlier times, they used to go after these giant in a boat hardly bigger than a canoe.

(in Russian) В прежние времена, они отправлялись за гигантами в лодке, едва больше чем каноэ.

(in Persian). Dar zamanhaye naxostin anha adat dashtand beravand be donbale in golha dar gayegi ke benodrat bozorgtar az yek zorag bood.

(in Azari). Ovvəllər onlar kanoedən bir az böyük qayıqda gedərdilər.

Large, in contrast, occurs with many nouns of this type, which strengthens the impression that in this corpus at least, large is preferred over big for describing purely physical size, especially for non-human things. Both big and large occur with Amounts, but the additional data suggests a slight semantic distinction between big and large when used with nouns of this type. The amount nouns which occur with big but not large--change, difference, discounts, and rise, are "dynamic" in meaning in that they describe changes in an amount; in contrast, most of the amount nouns which occur with large describe amounts of money or products which are relatively "stable" (although they can potentially undergo an increase or decrease), e.g., a fee is a set amount of money that is charged for a service, and an inventory is a listing of the amount of products that are in stock at a particular time. This difference between big and large is not absolute--as was shown above, big occurred with "stable" amounts such as profits and stakes, while large occurred with "dynamic" amounts such as cut and increase---but there is a tendency for big to be used to describe amounts of change.

It has been shown so far that when the overall uses of big and large are compared, they have many uses in common, but there are also a lot of differences; in particular, there are entire semantic categories of nouns which occur with big but not large and vice versa.

Another basic option in the system Measure - type is [class - property], which does not specify a measurable parameter, like [quantity], but the class of objects that are semantically considered as large or small. This feature covers 
uses of little thing in the example as well as big names, low achievers, deep feeling, etc. In several cases, the feature controls the choice between near-synonymous lexical items. For instance, a large fish refers to the physical size of a particular fish, while a big fish belong to the class of big fishes. The expression a large city is not idiomatic. It is normally used in expressions referring to the number of people living in it or the area it occupies uses of a big city are different. The big city is used to refer to a large city which seems attractive to someone because they think there are many exciting things to do there, and opportunities to earn a lot of money. So in the case of [non- directional] size specifications, the feature [quantity] is preferably realized by large, while the feature [class- property] by big. Pay attention to these examples:

(1) In the eighteenth century, cities became larger and more crowded.

(in Russian) В восемнадиатом столетии, города стали большими и более густо населенными.

(in Persian) Dar garne hejdahom, shahrha bozorgtar va shologtar shodand.

(in Azari) On səkkizinci əsrdə şəhərlər daha böyük və daha s1x əhalili oldu.

(2)....... tidings of this spreaded to all big cities, outskirt places, small villages as well.

(in Russian) ............новости об этом распространились в большие города, окраины а также в маленькие деревушки.

(in persian) ........... Sedaye in masale be tamamiye shahrhaye bozorg, homeye shahr va rostaha pakhsh shode bood.

(in Azari)........ bunun əks- sədası bütün böyük şəhərlərə, ucqar guçələrə, xırda kəndlərə də yayıldı.

By comparing the translations of the given examples in other languages it can be seen that both big and large are translated to большие in Russian, bozorg in Persian, and böyük in Azeri. But there is another fact about the translation of mentioned adjectives in Russian which is different from their translation in Persian and Azeri. In spite of the lack of differences between large and big in Persian and Azeri, these two adjectives sometimes can be translated differently in Russian language. Although in all of the given examples the mentioned adjective have been translated to большие (boljshoj ), they can be also translated to Krupnyj which expresses the meaning of [non-directional big]. As for differences between uses of boljshoj and krupnyj, boljshoj is used in a wider range of free constructions than krupnyj and most typically refers to the physical size of an arbitrary object. When krupnyj refers to the size, it is mostly restricted to certain types of objects, like the size of human persons (especially children), or body parts, or certain animate objects. The major groups of terminological collocations with krupnyj concern the font size, amount of money, or elements of a quantifiable object.

In translation, consequently, the translator ought to translate the communicative function of the source language text, rather than its signification. Thus for more considering pay attention to the following examples:

(1) She and her husband Peter had a large farm on an island.

(in Russian) У нее и ее мужа Питера была большая ферма на острове,

(in Persian) $O$ va shoharash, Piter, mazraeye bozorgi dar jazire dashtand.

(in Azari) $O$ vo ounun ori Peterin adada böyük bir ferması vard.

(2) I felt inside the bag a gain and found a big hole.

(in Russian) Я думал, что в сумке будет нажива, а нашел большую дырку.

(in Persian) Do bar toye pakat ra gashtam va fagat yek sorakhe bozorg yaftam

(in Azari) Mən çantanın içində kəsik hiss etdim va yekə bir deşik olduğunu gördüm.

(3) Mary has become a big girl. She is growing up fast.

(in Russian) Мэри стала взрослой девушкой. Она растет быстро.

(in Persian) Mery dokhtare bozorgi shode ast. O sari bozorg mishavad.

(in Azari) Meri böyük quz olub. O, çox tez böyüyür.

To sum up, the translation task becomes a complex process where either linguistic or non-linguistic elements provide the text with that nuance that makes it unique. For this reason, translators should demonstrate that they have developed both linguistic and communicative competence in the languages involved in their translating exercise in order to solve possible problems they may face during their professional practice. A translator must, therefore, look for a targetlanguage utterance that has an equivalent communicative function, regardless of its formal resemblance to original utterance as far as the formal structure is concerned. In other words, translation should operate or take place on the level of language use, more than usage.

\section{CONCLUSION}

The study reported in this paper shows an approaching for describing lexical semantics from the viewpoint of their uses in texts. This research showed that although both big and large, are near synonyms, this does not mean they are identical in meaning, and translator can choose each of them without paying attention to their contextual meaning; they are synonyms by virtue of the fact that they are associated with the same semantic dimension, but they are differentiated by the fact that they modify different kinds of nouns.

\section{REFERENCES}

[1] Charles, W. G. \& G. Miller. (1989). Contexts of antonymous adjectives. Applied Psycholinguistics, 10(3),357-75. 
[2] Cruse, D. A. (1986). Lexical Semantics. New York: Cambridge University Press.

[3] Dancette, J. (1997). Mapping meaning and comprehension processes in translation. Cognitive processes in Translation and interpreting. Retrieved November 10, 2008 from https://www.webdepot.umontreal.ca/Usagers/dancettj/MonDepotPublic/web/pdf/pdf_traducto/mapping_meaning2ddanks2d97. pdf.

[4] Deese, J. E. (1965). The associative structure of some common English adjectives. Journal of Verbal Learning and Verbal Behavior, (5), 347-57.

[5] Frawley, W. (1992). Linguistic semantics. Hillsdale, etc.: Lawrence Erlbaumn Associates.

[6] Gross, D., U. Fischer \& G. A. Miller. (1989). Antonym and the representation of adjectival meanings. Journal of Memory and Language, 28(1),92-106.

[7] Lang, E. (1989). The semantics of dimensional designation of spatial objects. In Bierwisch \& Lang .

[8] Lyons, J. (1977). Semantics. Cambridge, etc.: Cambridge University Press.

[9] Malmkjær, K. (1993). Underpinning translation theory. Target, 5(2), 133-148.

[10] Mel'chuk, I. A. (1988). Semantic description of lexical units in an Explanatory Combinatorial Dictionary: basic principles and heuristic criteria. International Journal of Lexicography, 1,165-188.

[11] Miller, G. A. (1978). Semantic relations among words. In Linguistic Theory and Psychological Reality, ed. M Halle, J Bresnan, GA Miller. Cambridge, MA: MIT Press.

[12] Nagy, W. E., R. C. Anderson \& P.A. Herman. (1987). Learning word meanings from context during normal reading. Am. Educ. Res. J. 24:237-70.

[13] Nilsson, P. O. (2002). An assessment of the translation-specificity of over-represented multi-word patterns in Swedish fiction texts translated from English. Linguistica Antverpiensia, New Series. Linguistics and Translation Studies, Translation Studies and linguistics (ed. by Leona Van Vaerenbergh), 1,407-417.

[14] Nord, C. (1997). Translating as a Purposeful Activity. Manchester: Jerome Publishing.

[15] Setton, R. (1999). Simultaneous interpretation: A cognitive-pragmatic analysis. Amsterdam and Philadelphia: John Benjamins.

[16] Smith E. E. (1978). Theories of semantic memory. In Handbook of Learning and Cognitive Processes: Linguistic Functions in Cognitive Theory, ed. WK Estes, 6,1-56. Hillsdale, NJ: Erlbaum.

[17] Venuti, L. (1998). The Scandals of Translation: Towards an Ethics of Difference. London: Routledge.

[18] Weydt, H. \& B. Schlieben-Lange. (1998). The meaning of dimensional adjectives. Discovering the semantic process. Lexicology, 4(2): 199-236.

[19] Zohrevandi, Z. (1992). Translation as a Resource. In R. de Beaugrande, A. Shunnaq and M. H. Heliel (Eds.) Language, Discourse and Translation in the West and Middle East. Amsterdam: John Benjamins.

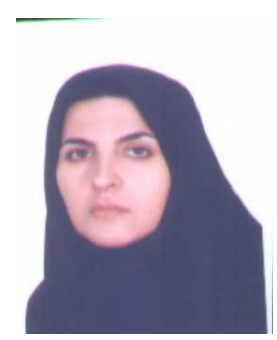

Malahat shabani Minaabad has lived in Namin, Ardabil, Iran since her childhood. She finished her primary and secondary schools in her hometown. Her major in BA was English language and literature, in $\mathrm{MA}$ teaching English as a foreign language, and $\mathrm{PhD}$ in general linguistic. She has got these degrees simultaneously in Azad university of Ardabil, in Khatam university of Tehran and Baku state university in Azerbaijan.

Currently, she is a professor at English language departments of Mohageg University in Ardabil, and she has been involved in teaching since 2001 .

Her main areas of interests are translation, linguistic and teaching. She has published so many articles in the field of language and linguistics in countries such as IRAN, Russia, Azerbaijan and Turkey. 